\title{
Article \\ Restoration Trajectories and Ecological Thresholds during Planted Urban Forest Successional Development
}

\author{
K. J. Wallace *(D), Bruce D. Clarkson and Bridgette Farnworth $\mathbb{D}$
}

Citation: Wallace, K.J.; Clarkson, B.D.; Farnworth, B. Restoration Trajectories and Ecological Thresholds during Planted Urban Forest Successional Development. Forests 2022, 13, 199. https://doi.org/10.3390/f13020199

Academic Editor: Francisco J. Escobedo

Received: 22 November 2021

Accepted: 20 January 2022

Published: 27 January 2022

Publisher's Note: MDPI stays neutral with regard to jurisdictional claims in published maps and institutional affiliations.

Copyright: (C) 2022 by the authors. Licensee MDPI, Basel, Switzerland. This article is an open access article distributed under the terms and conditions of the Creative Commons Attribution (CC BY) license (https:// creativecommons.org/licenses/by/ $4.0 /)$.
Environmental Research Institute, University of Waikato, Private Bag 3105, Hamilton 3240, New Zealand; clarkson@waikato.ac.nz (B.D.C.); bridgette.farnworth@outlook.com (B.F.)

* Correspondence: kwallace@waikato.ac.nz

\begin{abstract}
Successfully reconstructing functioning forest ecosystems from early-successional tree plantings is a long-term process that often lacks monitoring. Many projects lack observations of critical successional information, such as the restoration trajectory of key ecosystem attributes and ecological thresholds, which signal that management actions are needed. Here, we present results from a 65 ha urban temperate rainforest restoration project in Aotearoa New Zealand, where trees have been planted annually on public retired pasture land, forming a 14 years chronosequence. In 25 plots $\left(100 \mathrm{~m}^{2}\right.$ each), we measured key ecosystem attributes that typically change during forest succession: native tree basal area, canopy openness, non-native herbaceous ground cover, leaf litter cover, ground fern cover, dead trees, and native tree seedling abundance and richness. We also monitored for the appearance of physiologically-sensitive plant guilds (moss, ferns, and epiphytes) that may be considered ecological indicators of succession. Linear regression models identified relationships between all but one of the key ecosystem attributes and forest age (years since planting). Further, using breakpoint analysis, we found that ecological thresholds occurred in many ecosystem attributes during their restoration trajectories: reduced canopy openness ( $99.8 \%$ to $3.4 \%$; 9.6 years threshold), non-native herbaceous ground cover (100\% to $0 ; 10.9$ years threshold), leaf litter cover ( 0 to $95 \%$; 10.8 years threshold), and increased tree deaths ( 0 to $4 ; 11$ years threshold). Further, juvenile native plant recruitment increased (tree seedling abundance 0 to $\sim 150$ per $4 \mathrm{~m}^{2}$ ), tree seedling species richness ( 0 to 13 per $100 \mathrm{~m}^{2}$ ) and epiphytes colonized ( 0 to 3 individuals per $100 \mathrm{~m}^{2}$ ). These and other physiologically-sensitive plant guilds appeared around the 11 years mark, confirming their utility as ecological indicators during monitoring. Our results indicate that measurable, ecological thresholds occur during the restoration trajectories of ecosystem attributes, and they are predictable. If detected, these thresholds can inform project timelines and, along with use of ecological indicators, inform management interventions.
\end{abstract}

Keywords: urban restoration; urban ecology; forest succession; tree regeneration; restoration ecology; ecological threshold; ecological function; ecological indicators; ecological trajectory; restoration trajectory

\section{Introduction}

\subsection{Urban Forest Restoration}

Urban centres and their associated human activity lead to a dramatic loss of native ecosystem cover [1]. Although urbanization generates environmental challenges, cities provide a unique context to restore native ecosystems for human well-being [2] and opportunities to develop the field of restoration ecology. Restored urban forests provide important ecosystem services [3], such as reducing greenhouse gases through carbon sequestration $[4,5]$, decreasing storm water runoff by absorbing rainwater $[2,6,7]$ and minimising the urban heat island effect by reducing ground surface and air temperatures [8]. Further, complex urban greenspaces, such as forests, can be havens for native biodiversity $[9,10]$ and enhance human health and well-being [11,12]. 
Restoring urban forests is becoming increasingly important because more than $50 \%$ of the world's population live in urban areas [1] and, for city residents, the only opportunity to enjoy nature is often at a local forested park. Urban forests therefore offer opportunities to support threatened species [13] and enhance ecosystem function through restoration [14], while simultaneously allowing people the manifold benefits of re-connection with nature $[13,15,16]$. However, to successfully restore urban forests, we must develop a comprehensive understanding of urban forest successional dynamics and the ways the urban context might constrain young tree plantings from developing into mature, ecologically functioning forests [17]. Restoring urban forests by trial and error is costly, and can often result in failures that discourage stakeholders and practitioners, and condemn future funding applications [18]. After the initial plantings occur, restoration practitioners require (1) predictive power about forest developmental trajectories, (2) tools to detect threshold points, and (3) knowledge of the ecological indicators that signal important changes in forest succession. These factors promote improved management, by forecasting the need for specific interventions (e.g., non-native herbaceous weed control or late-successional tree enrichment planting) to guide forest ecosystem restoration along a successful pathway

\subsection{Successional Development and Restoration Trajectories in the Urban Ecosystem Context}

Addressing differences in successional development (definition in Table 1) between urban and non-urban forests is relevant to restoration practice [3] because models based on non-urban forests may not accurately predict succession in urbanized environments [19]. Residential, industrial, and infrastructural landcover differences in urban areas creates distinctive challenges for urban forest restoration, including larger temperature fluctuations $[20,21]$, native landcover fragmentation [22,23], pollutants (e.g., light pollution [24,25] and chemical pollution [3]), and invasion by non-native species [26-28].

Acknowledging that continual anthropogenic pressure alters natural disturbance regimes and shapes successional development by redirecting restoration trajectory ([29]; Table 1) allows realistic goals to be set for urban restoration management. Appropriate goals will improve management and lead to successful social, economic and ecological outcomes $[19,29,30]$. Anticipating the urban context and its influence on the restoration of planted forests is critical and requires knowledge of succession theory to (i) guide the ecosystem's successional development, but also (ii) to understand individual restoration trajectories of key ecosystem attributes (e.g., canopy openness; Table 1), and (iii) select the most useful ecological indicators of success (e.g., plant guilds physiologically sensitive to urban climates).

Table 1. Definition of terms discussed in the context of this paper.

\begin{tabular}{ccc}
\hline Term & Definition as Used in this Paper & Related Refs. \\
\hline & $\begin{array}{c}\text { Also sometimes known as 'ecological succession'. Succession theory defines as the } \\
\text { process of a change in species structure of an ecological community over time. This } \\
\text { results largely from modification of the physical environment by the species present } \\
\text { and is somewhat predictable and therefore a process that ecological restoration often } \\
\text { seeks to mimic. Here we assume successional development should occur in } \\
\text { restoration projects following an anthropogenic disturbance and subsequent } \\
\text { development }\end{array}$ & $\begin{array}{c}\text { restoration action and the goal is to reach a 'mature', 'climax' or 'stable' functioning } \\
\text { ecosystem possibly sustained at an 'equilibrium'. }\end{array}$ \\
\hline $\begin{array}{c}\text { Key } \\
\text { ecosystem } \\
\text { attribute }\end{array}$ & $\begin{array}{c}\text { Also sometimes known as 'key ecological attribute' or 'community attribute'. These } \\
\text { are measurable properties of an ecosystem that are useful in monitoring or otherwise } \\
\text { quantitatively assessing function or biodiversity and they are often drivers of }\end{array}$ \\
\hline successional development. They are helpful characteristics to monitor when assessing \\
progress toward a target state for the ecosystem.
\end{tabular}


Table 1. Cont.

\begin{tabular}{ccc}
\hline Term & Definition as Used in this Paper \\
\hline $\begin{array}{c}\text { Restoration } \\
\text { trajectory }\end{array}$ & $\begin{array}{c}\text { Also sometimes known as 'ecological trajectory'. The pathway of development taken } \\
\text { by either an entire ecological community or individual ecosystem attribute during the } \\
\text { process of restoration. In this paper we use the concept when referring to individual } \\
\text { key ecosystem attributes. }\end{array}$ \\
\hline $\begin{array}{c}\text { Ecological } \\
\text { threshold }\end{array}$ & $\begin{array}{c}\text { An ecological threshold is the point at which there is an abrupt change in an } \\
\text { produce large responses in the ecosystem. A threshold can often signal a rapid shift or } \\
\text { change from one state or successional stage of the ecosystem to another. }\end{array}$ \\
\hline $\begin{array}{l}\text { Ecological } \\
\text { indicator }\end{array}$ & $\begin{array}{c}\text { The appearance or occurrence of a specified abiotic or biotic property that signals a } \\
\text { condition or state of the wider ecosystem. Ecological indicators may differ widely in } \\
\text { their specification, depending on their application, and in this paper we discuss in the } \\
\text { context of those that may be of most use during urban forest restoration. }\end{array}$ \\
\hline [7,42-44]
\end{tabular}

Successional development of an entire ecosystem encompasses many possible trajectories (e.g., retrogressive, direct regeneration, divergent, convergent) and change in various communities or taxa offers restoration insights into how species' attributes can reflect changes in community structure [45]. Successional development and active restoration are tightly coupled because 'succession' gauges species composition change through time and restoration is the deliberate manipulation of that change [45]. We must therefore understand the possible successional development pathways of urban forest ecosystems, as well as trajectories of their constituent key ecosystem attributes. For example, tree basal area and canopy openness are key constituent metrics of succession with regard to vegetation structure [46].

In addition to being good measures of the current state of the entire ecosystem's successional development, some key ecosystem attributes can be cost-effective and time efficient to measure, providing relationships between forest structural complexity and recovery of other ecosystem components [47]. The key ecosystem attribute of canopy openness in cohort restoration plantings of pioneer tree species can be especially telling, particularly when these trees naturally senesce after a few decades [48]. Tree death creates canopy gaps and signals an important window for enrichment planting of mid- or latesuccessional species. In fragmented city landscapes with limited native seed rain, the development of these canopy gaps can enable invasive non-native plants to re-establish, so the timing of appropriate management actions is essential. Continual monitoring to understand the restoration trajectory of a key ecosystem attribute, such as canopy openness, will allow managers to pre-empt invasive non-native plant re-invasion.

\subsection{Ecological Thresholds and Indicators in Restoration}

As successional development of an ecosystem occurs over time there are discrete points of note. These points may be called ecological thresholds (Table 1), where there is a significant change in the restoration trajectory of a key ecosystem attribute, that is sometimes signaled by the appearance of an ecological indicator (Table 1; Figure 1). Ecological indicators are observable and measurable quantities that have great utility because they provide important information on the ecosystem condition [49]. For example, the appearance of physiologically-sensitive plant species that are typically associated with stable, moist conditions could be considered ecological indicators and their presence may suggest the understory microclimate has reached a threshold. 


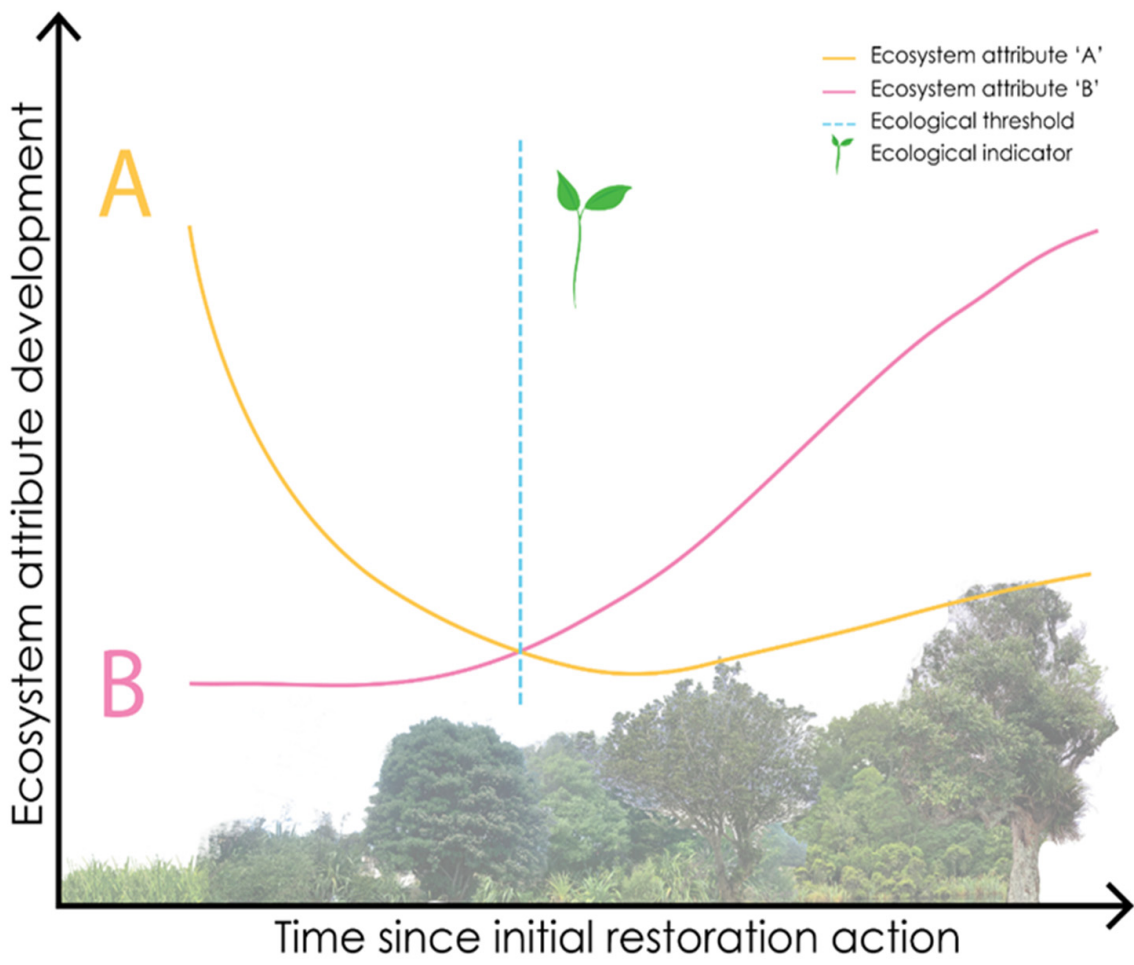

Figure 1. This conceptual diagram hypothesizes restoration trajectories of two key ecosystem attributes (represented by lines A and B) over time since initial restoration action was taken. When one or more attributes reach an ecological threshold (dashed, vertical blue line), ecological indicators may appear (green seedling icon). For example, within the context of urban forest restoration, a cohort of early-successional native tree plantings should grow over time and reduce canopy openness (e.g., Ecosystem attribute 'A') leaf litter cover is accruing on the forest floor (e.g., Ecosystem attribute ' $\mathrm{B}$ '). As each of these ecosystem attributes follows the pictured hypothetical restoration trajectory, a threshold may occur when Ecosystem attributes A and B reach a point in which understory conditions are ameliorated adequately to facilitate shade-tolerant mid- or late-successional plant species. This threshold may be signaled by spontaneous colonization (green seedling icon), which could be considered an ecological indicator. Knowledge of when ecological indicators should appear and when to look for them can inform management decisions. In this hypothetical scenario, when the green seedling indicator appears the management implication is that conditions are appropriate to plant mid- or late-successional enrichment species.

In urban forests, understanding ecological thresholds and their associated indicators can greatly support restoration efforts [18]. By monitoring planted forests as they grow from the early-successional stage and observing ecological indicators of successional development progress, we can assess if plantings are maturing to resemble a target forest ecosystem [50]. Easily-measured ecological indicators are useful for triggering specific management practices $[43,44]$. Indicators can be classified in three ways: composition, structure and function $[43,46,51,52]$. For example, composition may include indicators related to the diversity or abundance of flora and fauna; structure may indicate change in vegetation such as height, diameter and canopy closure; and function may include variables that measure ecosystem processes, such as diversity and abundance of bioindicators or specific trophic interactions [43]. Here, we define ecological indicators similarly to Lindenmayer et al. [53], where indicators are species or conditions that infer a particular restoration state, or species that reflect efforts to mitigate disturbance and are easily used as management indicators (also see Table 1).

Ecological indicators can denote the general ecosystem successional development (e.g., native species colonization $[43,54])$, or marked changes in individual key ecosystem attributes. For example, colonization by shade-tolerant plants, which require moist, sheltered 
microclimates (e.g., epiphytes), indicates successional development [55]. Regenerating tree species richness and abundance are the ultimate indicators of success for restoring a self-perpetuating forest ecosystem; however, they may only come after thresholds in some key ecosystem attributes eventuate, e.g., canopy openness, or stable understory microclimate [21]. In the years immediately following initial restoration activities, key ecosystem attributes should be monitored while looking for the appearance of ecological indicators to best inform on forest successional development. Monitoring is also critical in later stages of the restoration process (i.e., $>10$ years since initial plantings) because short-term data may not reveal long-term ecosystem responses [56].

Here, we present analysis on the successional development of a planted urban forest 14 years chronosequence. We evaluate restoration trajectories of key ecosystem attributes, detect ecological thresholds, and speculate about useful ecological indicators for the urban context. The goal is to better assess progress towards a functioning, self-perpetuating forest. We assessed early-successional tree plantings to identify: (i) general forest ecosystem successional development, (ii) change in constituent key ecosystem attributes, and (iii) ecological indicators of restoration success (e.g., physiologically-sensitive native plant colonization). We were particularly interested in the appearance of important ecological indicators that may mark jumps in ecosystem attribute recovery and have positive implications for native wildlife health (e.g., reproduction, migration activities, and population growth) and food web dynamics.

\section{Materials and Methods}

\subsection{Study Site}

Our site was situated within northwest Kirikiriroa Hamilton $\left(37.7870^{\circ}\right.$ S, $175.2793^{\circ}$ E; population 160,000) within the Waikato region of Aotearoa New Zealand. The area was historically heavily forested but now has $\sim 2.1 \%$ indigenous forest cover remaining [57]. Kirikiriroa Hamilton has an annual mean precipitation of $1110 \mathrm{~mm}$ with mean minimum and maximum temperatures of 8.7 and $18.9^{\circ} \mathrm{C}$, respectively. Data were collected from Waiwhakareke Natural Heritage Park (WNHP; Figure 2) a 65.5 ha area of public retired pasture land covered in non-native plants. Waiwhakareke Natural Heritage Park was once temperate lowland rainforest and wetland which is now being restored through active planting and ongoing management [58]. As of 2020, 37.3 ha has received pioneer plantings, with 10.7 ha of that also being enriched with mid-late-successional plant species.

Planting followed guidelines outlined in the operative management plan [59] which identifies target ecosystem planting composition based on topography and soils. Five main planting zones have been identified, each with a species composition suited to that zone type (Lake Zone, Riparian Zone, Wetland Zone, Hillslope, and Ridgetop [59]). Together, some 80 different native trees and shrubs are being used in the initial early-successional and late-successional plantings. Depending on successional status and expected size at maturity, plantings occur at densities of 50-200 plants per $100 \mathrm{~m}^{2}$, with small-maturing, early-successional species planted densely and large-maturing, late-successional species planted sparsely. Early-successional planting composition includes pioneer tree and shrub species historically found in the region, most from genera such as Pittosporum, Kunzea, Leptospermum, Hoheria and Coprosma. These species display typical early-successional species' characteristics such as tolerance to temperature swings and drought and require full sun conditions for their quick growth. They generally grow quickly but have short lifespans and therefore are only a first step in forest establishment and must be augmented with enrichment plantings of late-successional plant species. Late-successional species composition includes late-successional species typical of the region from genera such as Dacrycarpus, Dacrydium, Agathis, Alectryon, Beilschmiedia, and Hedycarya. Late-successional species' growth traits include slower growth, juveniles with less tolerance to swings in local climate conditions and more shade tolerance and longer lifespans. 


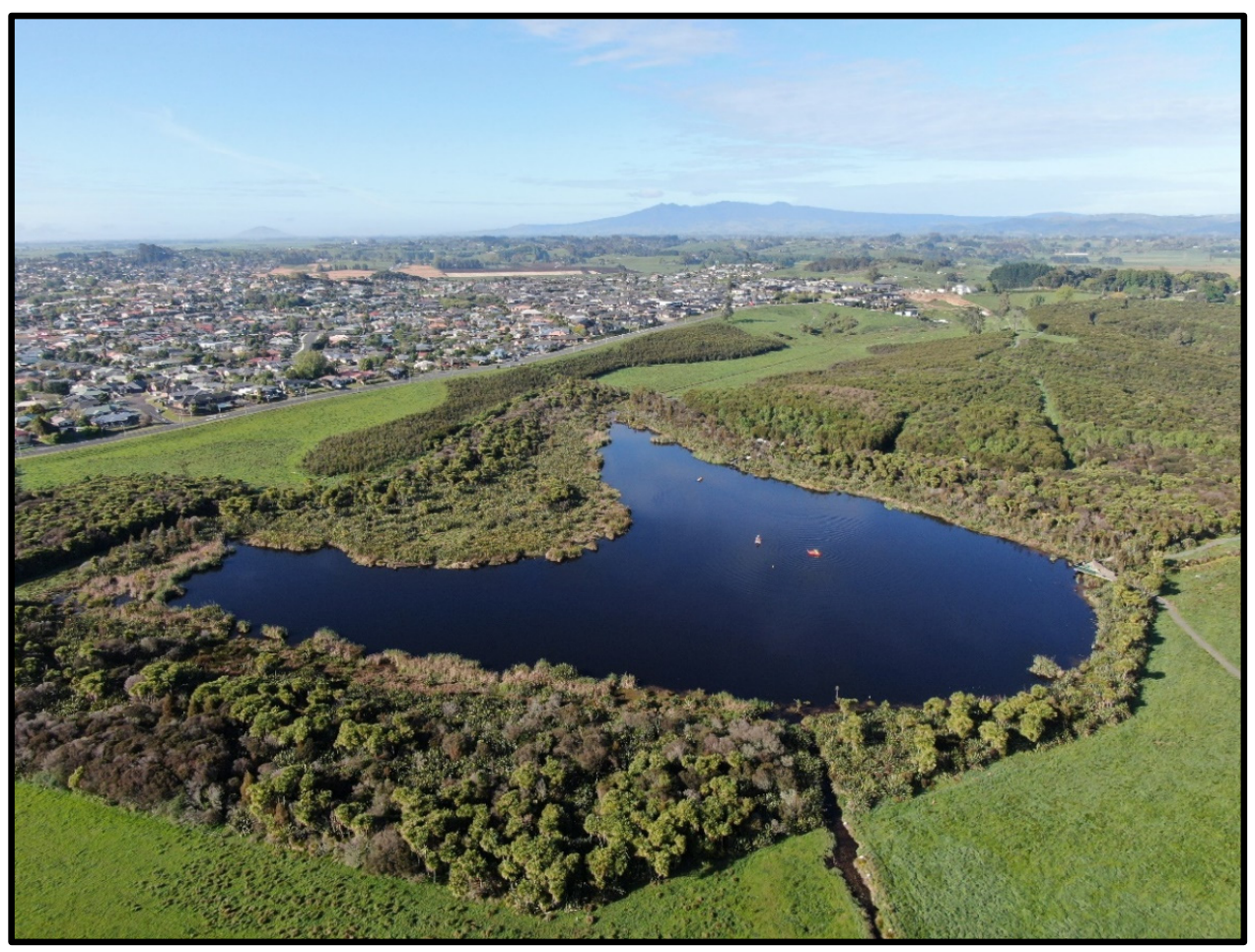

Figure 2. The research site, Waiwhakareke Natural Heritage Park in the city of Kirikiriroa Hamilton, Aotearoa New Zealand. This public land on the outskirts of the city is being restored with additional plantings every year. The entire area pictured was once severely modified pasture land and the aim is to return it to mature native temperate rainforest representative of the local region's vegetation. The current canopy consists largely of early-successional species. The park features low, rolling hills and a peat lake. Image credit: David G. Schmale III. (www.hamilton.govt.nz/our-city/parks / parksandgardens/waiwhakareke/Pages/default.aspx) (accessed on10 November 2021).

Plantings of native species have occurred annually over the last 14 years, forming a chronosequence. Chronosequences are space-for-time substitutions that can be used to understand the long-term processes that structure forests [60] and allow us to provide a novel perspective on how succession theory can be applied to the ecological restoration of forests within city landscapes.

\subsection{Data Collection}

We collected data on key ecosystem attributes from 25 permanent plots $\left(100 \mathrm{~m}^{2 /}\right.$ plot $)$ that span across different planting ages in the 14 years chronosequence (2004-2017; Figure 3). In each plot, canopy openness was measured at four locations (at each plot corner) by taking densiometer measurements of light transmission from $1.4 \mathrm{~m}$ above the ground using a convex spherical densiometer (Convex model A; Forestry Suppliers, Jackson, MS, USA). The average value across the four plot locations was used to quantify plot-level canopy openness as an index of light availability in the forest understory.

All living adult trees $\geq 2.5 \mathrm{~cm}$ (single- and multi-stemmed individuals) diameter at breast height (DBH; $1.4 \mathrm{~m}$ ) within each plot were identified to species level, classified as native or non-native, and the $\mathrm{DBH}$ of each stem was recorded. We used these data to compute the basal area for adult tree species in each plot. All dead adult trees rooted within a plot were tallied but not otherwise measured. Saplings, defined as trees $<2.5 \mathrm{~cm}$ in DBH but $>1.4 \mathrm{~m}$ in height were tallied by species across the entire plot and classified as native or non-native. Seedlings, defined as $<2.5 \mathrm{~cm}$ in DBH and $<1.4 \mathrm{~m}$ in height were classified as native or non-native, and tallied within four $1 \mathrm{~m}^{2}$ sub-plots in each plot. Any woody plant that had at least one true leaf was considered a seedling. 


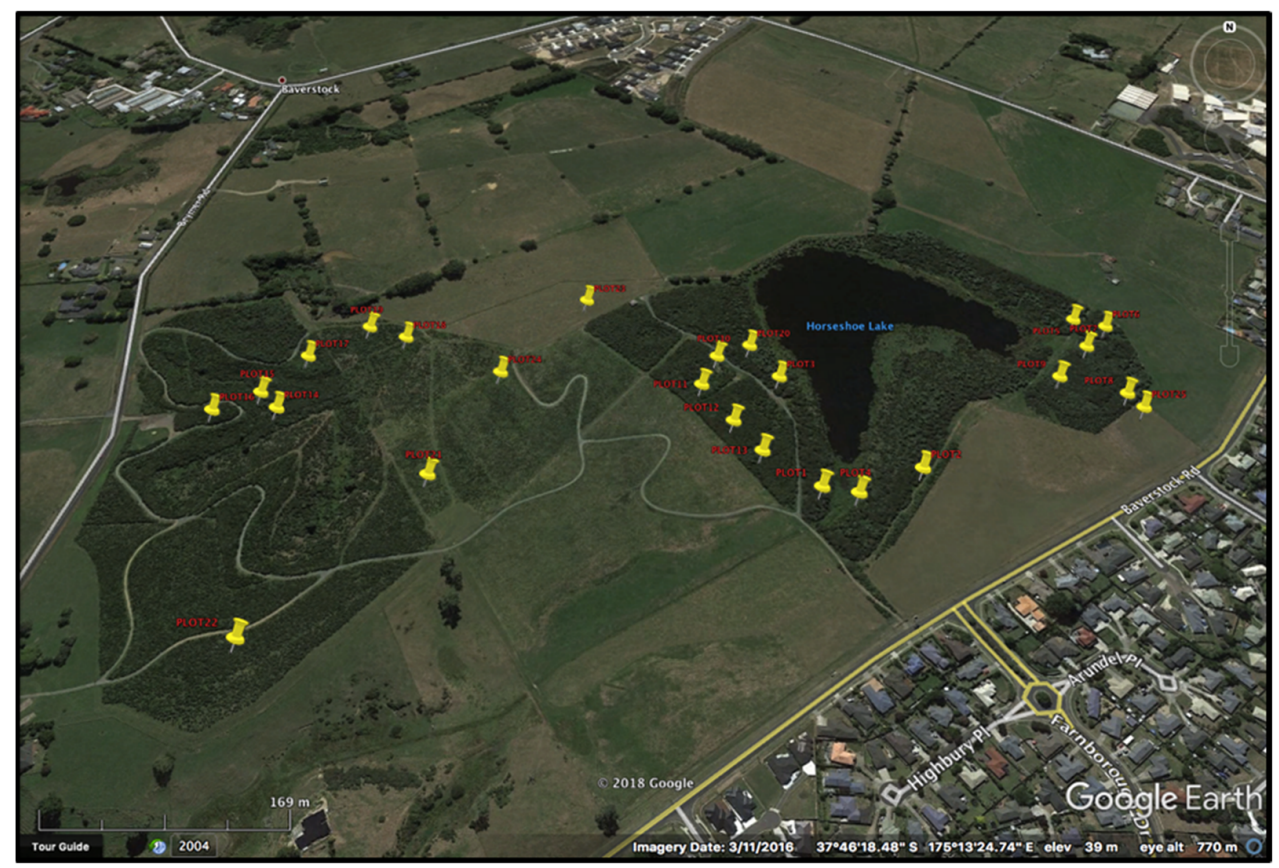

Figure 3. The 25 plot locations at Waiwhakareke Natural Heritage Park, each with a unique ID number. The plots form a chronosequence by spanning the range of planting years (2004-2017). Therefore, there is a marked difference in appearance between the different planting areas, with younger planting areas lighter in appearance and older ones showing up darker and more textured. The same data were collected in each plot to observe forest successional changes as related to planting age.

Epiphytes were defined as any obligate native epiphyte growing on an adult tree which was rooted within a plot (obligate epiphytes are those which must grow on trees [61]). Epiphytes were identified to species and tallied by number of host trees they occurred on [62].

Ground cover was assessed by percent cover across the entire plot and could not jointly exceed 100\% cover. The five categories assessed were (i) herbaceous plant species, (vast majority were non-native pasture plants), (ii) leaf litter and small woody detritus (except for entire dead trees which were assessed separately), (iii) bare ground, (iv) moss or (v) ferns.

Some of the areas that older plots were located in had been enriched with latesuccessional plantings at the time of data collection; however, records detailing which ones and what enrichment species were planted were not available. We do not consider this problematic as here we focus on understanding the relationship between ecosystem conditions at time of data collection and what plant species were able to persist under those conditions.

\subsection{Data Analysis}

To evaluate planted forest successional development, we inspected bivariate plots to understand the relationship between forest age and the different ecosystem attributes (e.g., canopy openness, native adult tree basal area, and seedling abundance). First, we fitted generalized linear regression models to these data to determine the general shape of the restoration trajectory. If a breakpoint (i.e., threshold) appeared likely, we then used the "segmented" package [63] in R [64] to pinpoint it statistically and therefore precisely detect these critical transitions in trajectories of ecosystem properties. Any significant breakpoints were included in the final regression model if they improved the fit. Prior to fitting the models, the variables native tree basal area and native tree seedling species richness were $\log$ transformed. Native adult tree basal area was expressed in units $\mathrm{m}^{2} / \mathrm{ha}$, to align with 
standard measures of basal area in forestry practice. All statistical analyses were performed in R using the "vegan" package [65].

\section{Results}

\subsection{Canopy Changes}

All adult trees recorded were native. There was a significant relationship between forest planting age and native adult tree basal area. We found that they increase together in a predictable, linear fashion, with no thresholds detected (Figure 4A). The greatest basal area occurred at 12 years $\left(38.5 \mathrm{~m}^{2} / \mathrm{ha}\right)$, and at 11 years, when many other key ecosystem attributes experienced a threshold, and averaged $25.2 \mathrm{~m}^{2} /$ ha. The lowest basal area value $\left(0 \mathrm{~m}^{2} / \mathrm{ha}\right)$ occurred in younger plots ( 1 and 2 years after planting) because none of the plantings were large enough to qualify as adult trees.

(A) Native Tree Basal Area

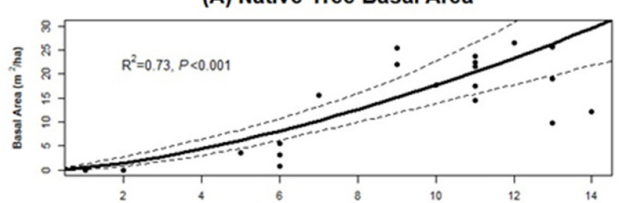

(C) Non-native Herbaceous Cover

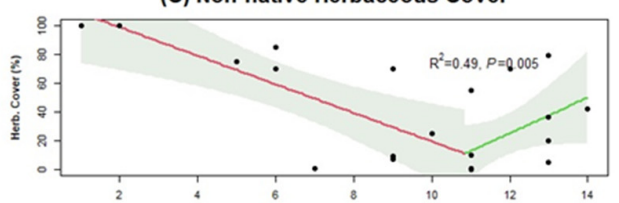

(E) Fern Cover

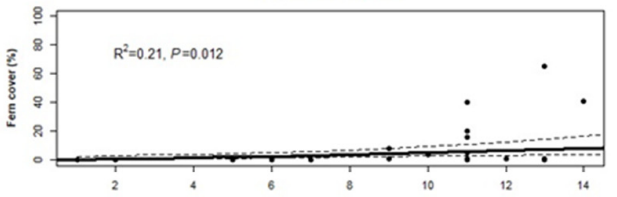

(G) Native Tree Seedling Abundance

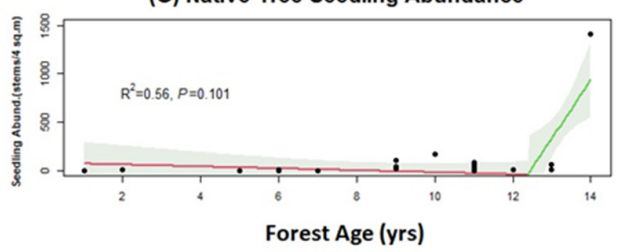

(B) Canopy Openness

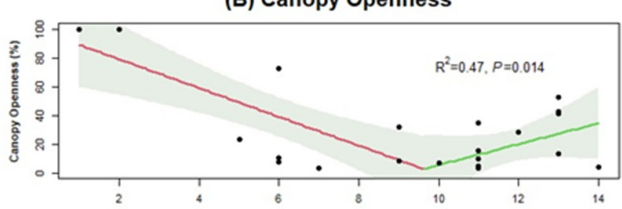

(D) Leaf Litter Cover

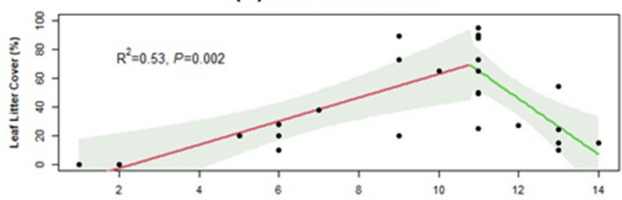

(F) Dead Trees

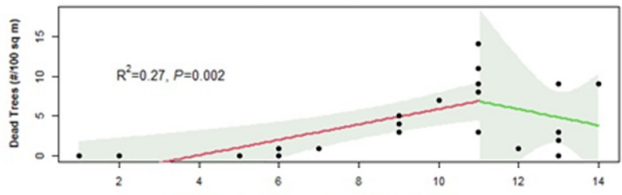

(H) Native Tree Seedling Richness

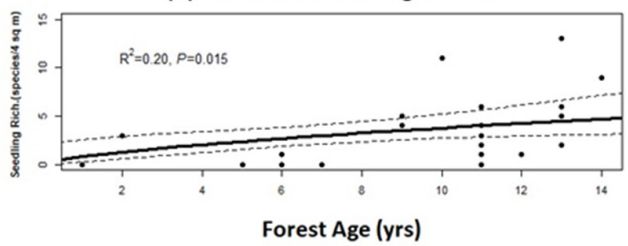

Figure 4. Successional development of key ecosystem attributes and ecological indicators within planted urban forest plots (plot size $=100 \mathrm{~m}^{2}$ ) that range between 1 and 14 years in age since planting. We show ecosystem attributes that have changed most drastically since initial planting, many of which display thresholds in their developmental trajectories. Forest age is shown on the $\mathrm{x}$-axis and units are in years. Scatterplot points represent each of the 25 plots data were collected in; some points overlap with each other almost completely in graph space, causing fewer than 25 to be visible in some cases. The solid lines represent the fitted values from linear regression models, and $95 \%$ confidence intervals are shown for piecewise linear regression models with significant thresholds by using shading, whereas for linear regression models without thresholds detected, 95\% confidence intervals are shown by using dashed lines. (A) Native tree basal area $\left(\mathrm{m}^{2} / \mathrm{ha}\right)$ had a significant relationship with forest age but no detectable threshold, (B) canopy openness (\% cover) had a significant relationship with forest age and a threshold at 9.6 years, (C) non-native herbaceous cover had a significant relationship with forest age and a threshold at 10.9 years, (D) leaf litter cover had a significant relationship with forest age and a threshold at 10.8 years, (E) fern cover had a significant relationship with forest age but no threshold, (F) dead trees had a significant relationship with forest age and a threshold at 11 years, $(\mathbf{G})$ native tree seedling abundance had a marginally significant relationship with forest age and a threshold at 12.4 years, and $(\mathbf{H})$ native tree seedling richness had a significant relationship with forest age but no detectable threshold. 
In contrast, while basal area increased with forest age, we found a significant inverse relationship between forest age and canopy openness (Figure 4B). A steep drop from $99.8 \%$ canopy openness to $3.4 \%$ openness occurred with a threshold at 9.6 years after planting. After this threshold, canopy openness slowly increased.

\subsection{Ground Covers and Dead Trees}

Ground cover summary measurements are summarised in Table 2, and those of note are also shown graphically with their associated statistical results (Figure $4 \mathrm{C}-\mathrm{E}$ ). Non-native herbaceous cover decreased with forest age, beginning at $100 \%$, and declining to $0 \%$, with a significant breakpoint at 10.9 years (Figure 4C; Table 2). Leaf litter cover accrued with forest age (Figure 4D) from $0 \%$ to $95 \%$ and peaked at 20 times greater than in youngest plots, with a significant breakpoint at 10.8 years (95\% cover; Table 2$)$, after which it declined. Ferns began to appear approximately 10 years after initial plantings and increased with age to $65 \%$ cover in the years following, but without a significant breakpoint detected (Figure $4 \mathrm{E}$; Table 2). There was generally little bare ground (no more than 15\%, with the exception of $60 \%$ in one 7 -years-old plot; Table 2 ), which was marginally inversely related to forest age $\left(\mathrm{R}^{2}=0.30, \mathrm{P}=0.063\right.$; threshold 7 years $)$. Moss cover displayed a marginally significant increase during forest development $\left(\mathrm{R}^{2}=0.09, \mathrm{P}=0.074\right)$, but no breakpoint was evident. Moss was completely absent in plantings seven years or younger and only occurred in very low quantities thereafter ( $1 \%$ cover; Table 2$)$. The number of dead adult trees significantly increased with forest age (threshold 11 years; Figure 4F).

Table 2. Ground covers measured in five categories: non-native herbaceous plants, leaf litter, bare ground, moss or ferns, displayed as percent cover with relation to forest age. ${ }^{*}$ Significant breakpoint detected.

\begin{tabular}{|c|c|c|c|c|c|}
\hline \multirow[b]{2}{*}{ Forest Age (y) } & \multicolumn{5}{|c|}{ Ground Cover Category (Percent Cover) } \\
\hline & $\begin{array}{c}\text { Non-Native } \\
\text { Herbaceous Plants * }\end{array}$ & Leaf Litter * & Bare Ground * & Moss & Fern \\
\hline 1 & 100 & 0 & 0 & 0 & 0 \\
\hline 2 & 100 & 0 & 0 & 0 & 0 \\
\hline 5 & 75 & 20 & 5 & 0 & 0 \\
\hline 6 & 85 & 10 & 5 & 0 & 0 \\
\hline 6 & 70 & 28 & 2 & 0 & 0 \\
\hline 6 & 70 & 20 & 10 & 0 & 0 \\
\hline 7 & 1 & 38 & 60 & 1 & 0 \\
\hline 9 & 70 & 20 & 1 & 1 & 8 \\
\hline 9 & 7 & 89 & 2 & 1 & 1 \\
\hline 9 & 9 & 73 & 15 & 2 & 1 \\
\hline 10 & 25 & 65 & 5 & 1 & 4 \\
\hline 11 & 55 & 25 & 4 & 0 & 16 \\
\hline 11 & 10 & 65 & 5 & 0 & 20 \\
\hline 11 & 0 & 49 & 10 & 1 & 40 \\
\hline 11 & 0 & 50 & 8 & 2 & 40 \\
\hline 11 & 0 & 95 & 5 & 0 & 0 \\
\hline 11 & 1 & 90 & 4 & 0 & 5 \\
\hline 11 & 1 & 88 & 10 & 0 & 1 \\
\hline 11 & 10 & 73 & 15 & 1 & 1 \\
\hline 12 & 70 & 27 & 1 & 1 & 1 \\
\hline 13 & 20 & 10 & 5 & 0 & 65 \\
\hline 13 & 5 & 24 & 5 & 1 & 65 \\
\hline 13 & 79 & 15 & 5 & 0 & 1 \\
\hline 13 & 36.56 & 54.31 & 6 & 3.13 & 0 \\
\hline 14 & 42 & 15 & 1 & 1 & 41 \\
\hline
\end{tabular}




\subsection{Native Plant Regeneration in the Understory \\ 3.3.1. Tree Seedlings}

The total abundance of native tree seedlings had a significant positive relationship with forest age and a threshold was detected (Figure 4G; threshold 12.4 years). The plot with the greatest number of native seedlings (1416) was in the oldest forest planting (14 years). In this plot the most abundant seedling species was Dacrycarpus dacrydioides (white pine, kahikatea; 1270), followed by Cordyline australis (cabbage tree, tī kōuka; 93). Native seedlings had a large increase in numbers measured after the threshold point at 12.4 years. The most abundant seedling species across all plots were $D$. dacrydioides (white pine, kahikatea: 1299), Melicytus ramiflorus (whitey wood, māhoe: 297), C. australis (cabbage tree, tī kōuka: 164) and Coprosma tenuicaulis (swamp coprosma, hukihuki: 130).

Non-native seedling abundance was comparatively low regardless of forest age (always $<15$ seedlings $\left./ 4 \mathrm{~m}^{2}\right)$ with no significant relationship with forest age $\left(R^{2}=0.03\right.$, $p=0.200)$. Native seedling species richness had a significant positive relationship with forest age, with older forests hosting more species (Figure $4 \mathrm{H}$ ). The number of species was greatest in plots over ten years old, but there was no breakpoint detected. Greatest species richness (13 species) occurred in a 13-years-old forest. Non-native tree seedling species richness did not change significantly with forest age $\left(\mathrm{R}^{2}=0.05, p=0.147\right)$ and remained low across all plots (the maximum number of species found was four in a 10 -years-old forest). Overall, fewer non-native species are successfully establishing than natives are regenerating.

\subsubsection{Saplings and Epiphytes}

There was no relationship between sapling abundance and forest age for either native $\left(R^{2}=-0.03, p=0.619\right)$ or non-native $\left(R^{2}=-0.01, p=0.414\right)$ species. Native saplings had highest abundance in 11-years-old (84 saplings) and 13-years-old forest (61 saplings). Very few non-native saplings were present (maximum abundance in any of the plots was three in a 14-years-old forest).

Four native epiphyte individuals were recorded (all Pyrrosia elaeagnifolia, leather-leaf fern) three of which were found in 11-years-old forest, and one in 14-years-old forest. This species is well known as an early colonizer [66]. There were not enough epiphytes found to successfully model their presence in relation to forest age.

\section{Discussion}

Our results suggest that the successional development of planted urban forests is predictable, and that the signs of succession can be quantified by measuring key ecosystem attributes (such as native adult tree biomass, canopy closure, decreased non-native plant invasion, turnover of early-successional canopy tree species, and development of understory conditions promoting native plant colonization). In addition, our chronosequence design examined the restoration trajectories of key ecosystem attributes and detected ecological thresholds. We have identified important ecological indicators in urban forest restoration.

\subsection{Ecological Trajectories of Key Ecosystem Attributes}

Key ecosystem attributes demonstrated one of three restoration trajectory shapes: linear (e.g., basal area, fern cover, native tree seedling richness), initially negative followed by a switch to a positive relationship after threshold (e.g., canopy openness, non-native herbaceous cover, native tree seedling abundance), or initially positive followed by a switch to a negative relationship after threshold (e.g., leaf litter cover, dead trees).

A linear trajectory with a single equilibrium endpoint is historically assumed to be how all ecosystem attributes develop [31,67]. This trajectory shape certainly exists here and been found elsewhere; example, e.g., after prescribed burning there is a linear increase in desired prairie species richness [68]. Attributes with this trajectory may not be as important for consideration during management because there is no critical threshold at which management intervention is important. Rather than trajectory shape, however, the 
slope, or temporal aspect of the trajectory may be important to observe. Here, we note a fairly rapid positive increase in native adult tree basal area, and while there is a similar trajectory shape demonstrated by fern cover and native tree seedling richness, the slope is much flatter, signaling a slower developmental timeframe which may require different practitioner planning.

The other two types of non-linear trajectories with distinct thresholds are interesting to consider as they are more dynamic, helpful attributes for signaling important points in successional development. For example, in our results, after the first decade of canopy closure, a distinct slope change occurs that indicates the canopy begins to open again. This is likely indicating a turnover in canopy trees, perhaps as early-successional species senesce and contribute to gap formation $[69,70]$, which is an important moment for midand late-successional plant species establishment in the understorey (spontaneously or via enrichment planting) [71]. These non-linear results reflect dynamics hypothesized in our conceptual model (Figure 1) and demonstrate the possibility of multiple equilibrium states in an ecosystem attribute [37]. Especially in highly disturbed urban contexts, concerted management intervention may be required to push an ecosystem attribute past the threshold point towards a more desirable, perhaps more resilient equilibrium state [19]. For example, in wetland restoration, nitrogen supplementation has been demonstrated as important for shifting plant community height to a more desirable state, (but the effect did not persist after supplementation ceased) [72].

The trajectories of individual key ecosystem attributes may sometimes be entangled with those of other ecosystem attributes, and may therefore trigger changes in one another. For example, in our results, tree growth caused a closed canopy, limiting understorey light availability and consequently inhibiting growth of non-native herbaceous pasture light-demanding species, a cascading relationship found in other research [18]. Forest floor characteristics changed such that non-native herbaceous plants senesced and were replaced by increasing leaf litter and coarse woody debris dropped by the maturing trees. Building the litter layer ultimately boosts soil organic material, a primary requirement in functioning forests $[73,74]$. The combination of canopy closure and increased leaf litter will subsequently enhance nutrient cycling and improve conditions for native seedling establishment. [75]. Our findings support our hypothesis that the trajectories of ecosystem attributes may vary in shape over time, and that they can influence each other in fundamental ways (Figure 1).

\subsection{Ecological Thresholds and Suitable Indicators in Urban Forests}

Many of the thresholds we detected occurred approximately 11 years after initial restoration plantings, which suggests this as a critical point in successional development [39] of urban forest ecosystems undergoing restoration. This point in development may be driven by factors other than time since initial restoration action, such as local climate, original disturbance extent [37], canopy composition [48] or other ecosystem drivers not yet fully understand in threshold dynamics [41].

For example, the temporal scale found here is different from a similar study by Wallace et al. 2017 [21], which studied 27 restored urban forests in two Aotearoa New Zealand cities (Kirikiriroa Hamilton and Ngāmotu New Plymouth). Wallace et al. 2017 found that it took 20 years (versus 11 in the present paper) to reach similar native tree basal area values. Forest age differed between studies, but the adult native tree basal area values were very similar at the detected thresholds $\left(25.2 \mathrm{~m}^{2} /\right.$ ha here versus $27 \mathrm{~m}^{2} /$ ha in Wallace et al. 2017). Differences in forest age at similar basal areas may simply be due to different locations and therefore growing conditions. Additionally, one study encompasses plots scattered across two cities while the present study focusses on data from plots in just one location. The studies' findings agree that the ecosystem attribute basal area has a predictable threshold point during its restoration trajectory.

We propose several easily-detected ecological indicators for use during urban forest restoration; all are groups or guilds of physiologically-sensitive plants: moss, ferns, epiphytes, and native tree seedlings. None of these plant guilds occurred in younger 
planted forests, but appeared about a decade after initial tree plantings (moss 7 years; ferns 9 years; epiphytes 11 years; native tree seedlings 12 years). These are good ecological indicators (or perhaps 'indicator species') in urban forests because they signal a critical shift in understory conditions to a more stable, moister microclimate-an all-important shift for the dry, urban heat island context [20]. They also signal change in forest successional status from early to mid-successional communities of plants. To develop a complex forest structure, the typical sequence of events begins with an increase in planted tree size (basal area), followed by a subsequent decrease in canopy openness. Reduced canopy cover blocks sunlight and reduces fluctuations in air temperature, and ultimately generates a balanced microclimate [21]. The presence of ecological indicators can infer that this cascade of events has occurred and particular microclimate conditions have been met. At this point, practitioners might consider that restorative actions to mitigate prior anthropogenic disturbances are on a successful pathway [53].

Using the presence of ecological indicators such as physiologically-sensitive plant guilds is not a new concept [44]. For example, epiphytes are already considered an excellent indicator of forest restoration success [62]. However, the urban context is particularly poignant for their use as indicators because of the larger microclimatic swings [76], high habitat fragmentation, and resulting poor native seed rain [77]. Colonization by sensitive plants is therefore notable for urban forests because they unmistakably signal that more appropriate understory microclimate conditions have developed. Furthermore, their presence suggests that management action is appropriate because a critical stage in successional development of the planted forest has occurred [78]. Understanding that physiologicallysensitive plants are excellent ecological indicators is valuable for urban forest restoration practitioners, as they provide important implications for management at pivotal points in forest development, and are relatively easy to observe and measure.

\subsection{Implications for Management of Urban Forests Undergoing Restoration}

Our results show the latency between initial restoration plantings and canopy closure of approximately 11 years, when many thresholds in key ecosystem attributes were then detected and ecological indicators appeared. Therefore, management to facilitate successional development in the first decade should be directed towards reaching this predictable threshold by encouraging early-successional tree growth. Firstly, the time required to reach canopy closure could be expedited by ensuring initial plantings are dense (e.g., one plant per $\left.\mathrm{m}^{2}\right)$ and tall (>1 $\mathrm{m}$ in height) [18]. Additional management to encourage succession may include regular invasive non-native plant control that is well targeted so juvenile native plants are not collateral damage. In some places, vertebrate browsers (e.g., rabbits [Oryctolagus cuniculus], Australian possums [Trichosurus vulpecula]) and seed predators (e.g., mice [Mus musculus]) should be controlled.

Monitoring is vital, and use of several metrics is beneficial. By a decade post-planting, basal area and canopy closure should be evaluated and, if basal area of $\sim 25 \mathrm{~m}^{2} /$ ha and at least $90 \%$ canopy closure have developed, invasive non-native plant control efforts can be reduced. These basal area and canopy closure measurements together with appearance of ecological indicator species such as mosses, ferns, epiphytes or native tree seedlings also suggest enrichment planting of mid- and late-successional species can begin. Enrichment planting should focus most on species that cannot self-introduce due to dispersal limitation and lack of seed sources in the urban environment. When understory conditions are suitable in larger, rural forests recovering from disturbance, there is often mid- and late-successional seed introduction provided through bird and wind dispersal. However, in urban contexts, introduction of mid- and late-successional species through enrichment planting by people is sometimes the only way these species may return [77].

Enrichment planting should be done in the important time window of canopy gap formation to prevent non-native plant re-invasion and before too much canopy openness increase and change in understory conditions. Mid- and late-successional plant species established via enrichment planting have different physiological tolerances to understory 
conditions depending on their growth stage, known as the 'ontogenetic growth shift' $[79,80]$. While a mostly-closed canopy promotes suitable conditions for mid- and late-successional tree species' seedlings, this is often not the case as they grow into saplings. Once established, these more mature saplings often have greater light demands, and as a trade-off, are more tolerant of microclimatic stresses such as large swings in temperature (they then have larger carbon and water reserves) $[81,82]$. Saplings therefore do not rely as much on the protected conditions that a closed canopy provides (e.g., shelter from wind, heat, frost and desiccation). Because of this, the optimal timing to plant young, mid- and late-successional trees as enrichment species may only span a few years: after canopy closure has occurred, but before the early-successional trees senesce and canopy gaps re-form.

\section{Conclusions}

The restoration trajectory of planted urban forest ecosystems requires continual monitoring to gauge progress. As these planted forests develop, they may follow a predictable successional development framework and include critical points, such as ecological thresholds and indicators. Tracking forest growth (e.g., basal area and canopy closure) allows these points to be detected and creates opportunities to observe colonization by sensitive indicator plant guilds. By monitoring plantings, restoration practitioners can assist planted urban forests to cross ecological thresholds more effectively and continue managing forest development towards a self-sustaining, functioning ecosystem.

Author Contributions: Conceptualization and methodology, K.J.W.; formal analysis, K.J.W. and B.F.; data collection, K.J.W.; data curation, B.F.; writing-original draft preparation, B.F.; writing—review and editing, B.F., K.J.W. and B.D.C.; funding acquisition, B.D.C. All authors have read and agreed to the published version of the manuscript.

Funding: This research was funded by the research program People, Cities \& Nature, which is funded by a Ministry of Business Innovation and Employment (MBIE) [grant number UOWX1601] from the New Zealand government.

Informed Consent Statement: Not applicable.

Data Availability Statement: The data presented in this study and code used in analysis are openly available in figShare under Wallace, Kiri Joy; Clarkson, Bruce D.; Farnworth, Bridgette (2022): Wallace et al. 2022 Data and R code-Urban Forest Restoration. figshare. Dataset. https:/ / doi.org/ 10.6084/m9.figshare.18516476.v1 (accessed on 15 January 2022).

Acknowledgments: We thank the Hamilton City Council for granting land access and express gratitude to T. Cornes for field assistance, to M. Hall for technical help with Figure 1 and F. Hasan for creation of the graphical abstract.

Conflicts of Interest: B.D.C. was guest editor of the Special Issue this article was published in and as such took all precautions to remove himself from review duties or final decisions regarding publication of the article. The funders had no role in the design of the study; in the collection, analyses, or interpretation of data; in the writing of the manuscript, or in the decision to publish the results.

\section{References}

1. Grimm, N.B.; Faeth, S.H.; Golubiewski, N.E.; Redman, C.L.; Wu, J.; Bai, X.; Briggs, J.M. Global Change and the Ecology of Cities. Science 2008, 319, 756-760. [CrossRef] [PubMed]

2. Endreny, T.; Santagata, R.; Perna, A.; De Stefano, C.; Rallo, R.; Ulgiati, S. Implementing and managing urban forests: A much needed conservation strategy to increase ecosystem services and urban wellbeing. Ecol. Model. 2017, 360, 328-335. [CrossRef]

3. Piana, M.R.; Aronson, M.F.; Pickett, S.T.; Handel, S.N. Plants in the city: Understanding recruitment dynamics in urban landscapes. Front. Ecol. Environ. 2019, 17, 455-463. [CrossRef]

4. Nowak, D.J.; Crane, D.E. Carbon storage and sequestration by urban trees in the USA. Environ. Pollut. 2002, 116, 381-389. [CrossRef]

5. Nowak, D.J.; Crane, D.E.; Stevens, J.C. Air pollution removal by urban trees and shrubs in the United States. Urban For. Urban Green. 2006, 4, 115-123. [CrossRef] 
6. Xiao, Q.; McPherson, E.G. Rainfall interception by Santa Monica's municipal urban forest. Urban Ecosyst. 2002, 6, 291-302. [CrossRef]

7. Dobbs, C.; Escobedo, F.J.; Zipperer, W.C. A framework for developing urban forest ecosystem services and goods indicators Landsc. Urban Plan. 2011, 99, 196-206. [CrossRef]

8. Bowler, D.E.; Buyung-Ali, L.; Knight, T.M.; Pullin, A.S. Urban greening to cool towns and cities: A systematic review of the empirical evidence. Landsc. Urban Plan. 2010, 97, 147-155. [CrossRef]

9. Aronson, M.F.J.; La Sorte, F.A.; Nilon, C.H.; Katti, M.; Goddard, M.A.; Lepczyk, C.A.; Warren, P.S.; Williams, N.S.G.; Clilliers, S.; Clarkson, B.; et al. A global analysis of the impacts of urbanization on bird and plant diversity reveals key anthropogenic drivers. Proc. R. Soc. B Biol. Sci. 2014, 281, 20133330. [CrossRef]

10. Threlfall, C.G.; Williams, N.; Hahs, A.K.; Livesley, S. Approaches to urban vegetation management and the impacts on urban bird and bat assemblages. Landsc. Urban Plan. 2016, 153, 28-39. [CrossRef]

11. Brown, G.; Schebella, M.; Weber, D. Using participatory GIS to measure physical activity and urban park benefits. Landsc. Urban Plan. 2014, 121, 34-44. [CrossRef]

12. Breed, M.F.; Cross, A.T.; Wallace, K.; Bradby, K.; Flies, E.; Goodwin, N.; Jones, M.; Orlando, L.; Skelly, C.; Weinstein, P.; et al. Ecosystem Restoration: A Public Health Intervention. EcoHealth 2020, 18, 269-271. [CrossRef] [PubMed]

13. Soanes, K.; Lentini, P. When cities are the last chance for saving species. Front. Ecol. Environ. 2019, 17, 225-231. [CrossRef]

14. Elmqvist, T.; Setälä, H.; Handel, S.N.; van der Ploeg, S.; Aronson, J.; Blignaut, J.N.; Gómez-Baggethun, E.; Nowak, D.J.; Kronenberg, J.; de Groot, R. Benefits of restoring ecosystem services in urban areas. Curr. Opin. Environ. Sustain. 2015, 14, 101-108. [CrossRef]

15. Standish, R.J.; Hobbs, R.J.; Miller, J.R. Improving city life: Options for ecological restoration in urban landscapes and how these might influence interactions between people and nature. Landsc. Ecol. 2013, 28, 1213-1221. [CrossRef]

16. Mata, L.; Ramalho, C.E.; Kennedy, J.; Parris, K.M.; Valentine, L.; Miller, M.; Bekessy, S.; Hurley, S.; Cumpston, Z. Bringing nature back into cities. People Nat. 2020, 2, 350-368. [CrossRef]

17. Piana, M.R.; Hallett, R.A.; Aronson, M.F.J.; Conway, E.; Handel, S.N. Natural regeneration in urban forests is limited by early-establishment dynamics: Implications for management. Ecol. Appl. 2021, 31, e2255. [CrossRef]

18. Wallace, K.J.; Clarkson, B.D. Urban forest restoration ecology: A review from Hamilton, New Zealand. J. R. Soc. N. Z. 2019, 49, 347-369. [CrossRef]

19. Johnson, L.R.; Handel, S.N. Restoration treatments in urban park forests drive long-term changes in vegetation trajectories Ecol. Appl. 2016, 26, 940-956. [CrossRef]

20. Zipper, S.C.; Schatz, J.; Singh, A.; Kucharik, C.J.; Townsend, P.A.; Ii, S.P.L. Urban heat island impacts on plant phenology: Intra-urban variability and response to land cover. Environ. Res. Lett. 2016, 11, 054023. [CrossRef]

21. Wallace, K.J.; Laughlin, D.C.; Clarkson, B.D. Exotic weeds and fluctuating microclimate can constrain native plant regeneration in urban forest restoration. Ecol. Appl. 2017, 27, 1268-1279. [CrossRef] [PubMed]

22. Drinnan, I.N. The search for fragmentation thresholds in a Southern Sydney Suburb. Biol. Conserv. 2005, 124, 339-349. [CrossRef]

23. Clarkson, B.D.; Wehi, P.M.; Brabyn, L.K. A spatial analysis of indigenous cover patterns and implications for ecological restoration in urban centres, New Zealand. Urban Ecosyst. 2007, 10, 441-457. [CrossRef]

24. McIntyre, N.E. Ecology of Urban Arthropods: A Review and a Call to Action. Ann. Èntomol. Soc. Am. 2000, 93, 825-835. [CrossRef]

25. Farnworth, B.; Innes, J.; Kelly, C.; Littler, R.; Waas, J.R. Photons and foraging: Artificial light at night generates avoidance behaviour in male, but not female, New Zealand weta. Environ. Pollut. 2018, 236, 82-90. [CrossRef]

26. Trammell, T.L.E.; Ralston, H.A.; Scroggins, S.A.; Carreiro, M.M. Foliar production and decomposition rates in urban forests invaded by the exotic invasive shrub, Lonicera maackii. Biol. Invasions 2011, 14, 529-545. [CrossRef]

27. La Sorte, F.A.; Aronson, M.; Williams, N.; Celesti, L.; Cilliers, S.; Clarkson, B.D.; Dolan, R.W.; Hipp, A.; Klotz, S.; Kühn, I.; et al Beta diversity of urban floras among European and non-European cities. Glob. Ecol. Biogeogr. 2014, 23, 769-779. [CrossRef]

28. Morgan, D.K.J.; Waas, J.R.; Innes, J. An inventory of mammalian pests in a New Zealand city. N. Z. J. Zool. 2009, 36, 23-33. [CrossRef]

29. Hobbs, R.J.; Norton, D.A. Towards a Conceptual Framework for Restoration Ecology. Restor. Ecol. 1996, 4, 93-110. [CrossRef]

30. Suding, K.N.; Gross, K.L.; Houseman, G.R. Alternative states and positive feedbacks in restoration ecology. Trends Ecol. Evol. 2004, 19, 46-53. [CrossRef]

31. Odum, E.P. The Strategy of Ecosystem Development. Science 1969, 164, 262-270. [CrossRef] [PubMed]

32. Connell, J.H.; Slatyer, R.O. Mechanisms of Succession in Natural Communities and Their Role in Community Stability and Organization. Am. Nat. 1977, 111, 1119-1144. [CrossRef]

33. Pickett, S.T.A.; Collins, S.; Armesto, J.J. Models, mechanisms and pathways of succession. Bot. Rev. 1987, 53, 335-371. [CrossRef]

34. Hobbs, R.J.; Walker, L.R.; Walker, J. Integrating Restoration and Succession. In Linking Restoration and Ecological Succession; Walker, L.R., Walker, J., Hobbs, R.J., Eds.; Springer: New York, NY, USA, 2007; pp. 168-179.

35. Schick, A.; Porembski, S.; Hobson, P.R.; Ibisch, P.L. Classification of key ecological attributes and stresses of biodiversity for ecosystem-based conservation assessments and management. Ecol. Complex. 2019, 38, 98-111. [CrossRef]

36. Timpane-Padgham, B.L.; Beechie, T.; Klinger, T. A systematic review of ecological attributes that confer resilience to climate change in environmental restoration. PLoS ONE 2017, 12, e0173812. [CrossRef] 
37. Suding, K.N.; Gross, K.L. The dynamic nature of ecological systems: Multiple states and restoration trajectories. In Foundations of Restoration Ecology; Falk, D.A., Palmer, M., Zedler, J., Eds.; Island Press: Washington, DC, USA, 2006; pp. 190-209.

38. De Cáceres, M.; Coll, L.; Legendre, P.; Allen, R.B.; Wiser, S.K.; Fortin, M.; Condit, R.; Hubbell, S. Trajectory analysis in community ecology. Ecol. Monogr. 2019, 89, 1350. [CrossRef]

39. Groffman, P.M.; Baron, J.S.; Blett, T.; Gold, A.J.; Goodman, I.; Gunderson, L.H.; Levinson, B.M.; Palmer, M.A.; Paerl, H.W.; Peterson, G.; et al. Ecological Thresholds: The Key to Successful Environmental Management or an Important Concept with No Practical Application? Ecosystems 2006, 9, 1-13. [CrossRef]

40. Hobbs, R.J.; Norton, D.A. Ecological filters, thresholds, and gradients in resistance to ecosystem assembly. In Assembly Rules and Restoration Ecology; Island Press: Washington, DC, USA, 2004; pp. 72-94.

41. Suding, K.N.; Hobbs, R. Threshold models in restoration and conservation: A developing framework. Trends Ecol. Evol. 2009, 24, 271-279. [CrossRef]

42. Dale, V.H.; Beyeler, S.C. Challenges in the development and use of ecological indicators. Ecol. Indic. 2001, 1, 3-10. [CrossRef]

43. Gatica-Saavedra, P.; Echeverría, C.; Nelson, C.R. Ecological indicators for assessing ecological success of forest restoration: A world review. Restor. Ecol. 2017, 25, 850-857. [CrossRef]

44. Siddig, A.A.; Ellison, A.; Ochs, A.; Villar-Leeman, C.; Lau, M.K. How do ecologists select and use indicator species to monitor ecological change? Insights from 14 years of publication in Ecological Indicators. Ecol. Indic. 2016, 60, 223-230. [CrossRef]

45. Walker, L.R.; Walker, J.; del Moral, R. Forging a new alliance between succession and restoration. In Linking Restoration and Ecological Succession; Walker, L.R., Walker, J., Hobbs, R.J., Eds.; Springer: New York, NY, USA, 2007; pp. 1-18.

46. Ruiz-Jaen, M.C.; Aide, M.T. Restoration success: How is it being measured? Restor. Ecol. 2005, 13, 569-577. [CrossRef]

47. Swanson, M.E.; Franklin, J.F.; Beschta, R.L.; Crisafulli, C.M.; DellaSala, D.A.; Hutto, R.L.; Lindenmayer, D.B.; Swanson, F.J. The forgotten stage of forest succession: Early-successional ecosystems on forest sites. Front. Ecol. Environ. 2011, 9, 117-125. [CrossRef]

48. Laughlin, D.C.; Clarkson, B.D. Tree seedling survival depends on canopy age, cover and initial composition: Trade-offs in forest restoration enrichment planting. Ecol. Restor. 2018, 36, 52-61. [CrossRef]

49. Lorenz, C.; Van Dijk, G.M.; Van Hattum, A.G.M.; Cofino, W.P. Concepts in river ecology: Implications for indicator development. Rivers Res. Manag. 1997, 13, 501-516. [CrossRef]

50. Gann, G.D.; McDonald, T.; Walder, B.; Aronson, J.; Nelson, C.R.; Jonson, J.; Hallett, J.G.; Eisenberg, C.; Guariguata, M.R.; Liu, J.; et al. International principles and standards for the practice of ecological restoration. Second edition. Restor. Ecol. 2019, 27, S1-S46. [CrossRef]

51. Wortley, L.; Hero, J.-M.; Howes, M. Evaluating Ecological Restoration Success: A Review of the Literature. Restor. Ecol. 2013, 21, 537-543. [CrossRef]

52. Noss, R.F. Indicators for Monitoring Biodiversity: A Hierarchical Approach. Conserv. Biol. 1990, 4, 355-364. [CrossRef]

53. Lindenmayer, D.B.; Margules, C.R.; Botkin, D. Indicators of forest sustainability biodiversity: The selection of forest indicator species. Conserv. Biol. 2000, 14, 941-950. [CrossRef]

54. DeLuca, T.H.; Aplet, G.H.; Wilmer, B.; Burchfield, J. The unknown trajectory of forest restoration: A call for ecosystem monitoring. J. For. 2010, 108, 288-295.

55. Reid, J.L.; Chaves-Fallas, J.M.; Holl, K.D.; Zahawi, R.A. Tropical forest restoration enriches vascular epiphyte recovery. Appl. Veg. Sci. 2016, 19, 508-517. [CrossRef]

56. Cortina, J.; Amat, B.; Castillo, V.; Fuentes, D.; Maestre, F.; Padilla, F.; Rojo, L. The restoration of vegetation cover in the semi-arid Iberian southeast. J. Arid Environ. 2011, 75, 1377-1384. [CrossRef]

57. Clarkson, B.D.; Wehi, P.M.; Brabyn, L.K. Bringing Back Nature into Cities: Urban Land Environments, Indigenous Cover, and Urban Restoration; University of Waikato: Hamilton, New Zealand, 2007.

58. Clarkson, B.D.; Bryan, C.; Clarkson, F. Reconstructing Hamilton's Indigenous Ecosystems: The Waiwhakareke Natural Heritage Park; City Green: Singapore, 2012; Volume 4, pp. 60-67.

59. CBER. Waiwhakareke Natural Heritage Park Operative Management Plan; Hamilton City Council: Hamilton, New Zealand, 2011.

60. Walker, L.R.; Wardle, D.A.; Bardgett, R.D.; Clarkson, B.D. The use of chronosequences in studies of ecological succession and soil development. J. Ecol. 2010, 98, 725-736. [CrossRef]

61. Kirby, C.L. Field Guide to New Zealand's Epiphytes, Vines \& Mistletoes; University of Waikato: Hamilton, New Zealand, 2014.

62. Suganuma, M.S.; Durigan, G. Indicators of restoration success in riparian tropical forests using multiple reference ecosystems. Restor. Ecol. 2014, 23, 238-251. [CrossRef]

63. Muggeo, V.M.R.; Sciandra, M.; Tomasello, A.; Calvo, S. Estimating growth charts via nonparametric quantile regression: A practical framework with application in ecology. Environ. Ecol. Stat. 2013, 20, 519-531. [CrossRef]

64. R Core Team. R: A Language and Environment for Statistical Computing; R Foundation for Statistical Computing: Vienna, Austria, 2017.

65. Oksanen, J.; Blanchet, F.G.; Kindt, R.; Legendre, P.; Minchin, P.R.; O’Hara, R.B.; Simpson, G.L.; Solymos, P.; Henry, M.; Stevens, M.H.H.; et al. Vegan:community ecology package. 2015. Computer coding software package in R.

66. Oliver, W.R.B. New Zealand epiphytes. J. Ecol. 1930, 18, 1-50. [CrossRef]

67. Clements, F.E. Plant Succession: An Analysis of the Development of Vegetation; Carnegie Institution of Washington: Washington, DC, USA, 1916.

68. Copeland, T.E.; Sluis, W.; Howe, H.F. Fire Season and Dominance in an Illinois Tallgrass Prairie Restoration. Restor. Ecol. 2002, 10, 315-323. [CrossRef] 
69. Busing, R.T. Tree mortality, canopy turnover, and woody detritus in old cove forests of the southern appalachians. Ecology 2005, 86, 73-84. [CrossRef]

70. Guariguata, M.R.; Ostertag, R. Neotropical secondary forest succession: Changes in structural and functional characteristics. For. Ecol. Manag. 2001, 148, 185-206. [CrossRef]

71. Brown, N. The implications of climate and gap microclimate for seedling growth conditions in a Bornean lowland rain forest. J. Trop. Ecol. 1993, 9, 153-168. [CrossRef]

72. Lindig-Cisneros, R.; Desmond, J.; Boyer, K.E.; Zedler, J.B. Wetland restoration thresholds: Can a degradation transition be reversed with increased effort? Ecol. Appl. 2003, 13, 193-205. [CrossRef]

73. Caldeira, M.V.W.; Godinho, T.D.O.; Moreira, F.L.; Campanharo Ítalo, F.; Castro, K.C.; De Mendonça, A.R.; Trazzi, P.A. Litter as an Ecological Indicator of Forest Restoration Processes in a Dense Ombrophylous Lowland Forest. Floresta Ambient. 2019, $26,1$. [CrossRef]

74. Martinelli, L.; Lins, S.R.M.; dos Santos-Silva, J.C. Fine litterfall in the Brazilian Atlantic Forest. Biotropica 2017, $49,443-451$. [CrossRef]

75. Yelenik, S.G. Linking dominant Hawaiian tree species to understory development in recovering pastures via impacts on soils and litter. Restor. Ecol. 2016, 25, 42-52. [CrossRef]

76. Ziter, C.D.; Pedersen, E.J.; Kucharik, C.J.; Turner, M.G. Scale-dependent interactions Oliveirabetween tree canopy cover and impervious surfaces reduce daytime urban heat during summer. Proc. Natl. Acad. Sci. USA 2019, 116, 7575-7580. [CrossRef] [PubMed]

77. Overdyck, E.; Clarkson, B.D. Seed rain and soil seed banks limit native regeneration within urban forest restoration plantings in Hamilton City, New Zealand. N. Z. J. Ecol. 2012, 36, 177-190.

78. Bertacchi, M.I.F.; Amazonas, N.T.; Brancalion, P.H.S.; Brondani, G.E.; de Oliveira, A.C.S.; De Pascoa, M.A.R.; Rodrigues, R.R. Establishment of tree seedlings in the understory of restoration plantations: Natural regeneration and enrichment plantings. Restor. Ecol. 2015, 24, 100-108. [CrossRef]

79. Oldfield, E.E.; Warren, R.J.; Felson, A.; Bradford, M. FORUM: Challenges and future directions in urban afforestation. J. Appl. Ecol. 2013, 50, 1169-1177. [CrossRef]

80. Young, T.P.; Petersen, D.A.; Clary, J.J. The ecology of restoration: Historical links, emerging issues and unexplored realms. Ecol. Lett. 2005, 8, 662-673. [CrossRef]

81. Urza, A.K.; Weisberg, P.J.; Chambers, J.C.; Sullivan, B.W. Shrub facilitation of tree establishment varies with ontogenetic stage across environmental gradients. New Phytol. 2019, 223, 1795-1808. [CrossRef]

82. Grubb, P.J. The maintenance of species-richness in plant communities: The importance of the regeneration niche. Biol. Rev. 1977, 52, 107-145. [CrossRef] 